\title{
ГИДРОТЕРМАЛЬНЫЙ НАНОКРЕМНЕЗЕМ В СЕЛЬСКОХОЗЯЙСТВЕННОМ РАСТЕНИЕВОДСТВЕ И БИОТЕХНОЛОГИИ
}

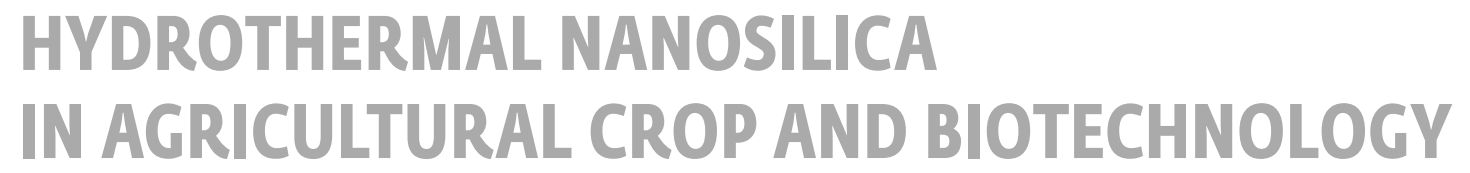

В.Н.Зеленковв ${ }^{1,2}$, д.с.-х.н., проф., гл. науч. сотр., (ORCID: 0000-0001-5481-2723) / В.В.Потаповз , д.т.н., проф., гл. науч. сотрудник, (ORCID: 0000-0001-6959-3324) / zelenkov-raen@mail.ru

V.N.Zelenkov1,2, Doct. of Sc. (Agriculture),Prof., Senior Researcher, (ORCID: 0000-0007-5487-2723), V.V.Potapov³, Doct. of Sc.(Technical), Prof., Chief Researcher, (ORCID: 0000-0001-6959-3324)

DOI: 10.22184/1993-8578.2020.13.1.22.33

Получено: 14.01.2020 г.

Выполнены эксперименты по применению гидротермального нанокремнезема для повышения урожайности сельскохозяйственных растений лекарственного и овощного применения. Золь нанокремнезема получали ультрафильтрационным мембранным концентрированием полимеризованной ортокремниевой кислоты гидротермального раствора до содержания $\mathrm{SiO}_{2}$ 10-20 мас. \%. Обработку растений проводили золем, разбавленным до содержания $\mathrm{SiO}_{2}$ в области 0,0001-0,2 мас. \%. Применяли обработку семян, либо внекорневой массы растений в разном возрасте однократно либо двухкратно. Расход $\mathrm{SiO}_{2}$ составлял 10-20 г/га. Эксперименты проведены с широким рядом растений: картофель, амарант, томаты, кабачок, горчица, капуста, лук, яровая пшеница, сахарная свекла, редис. Кроме урожайности, после обработки изменялись биохимические показатели разных частей растений (в некорневой и корневой массе) и биометрические показатели: высота, число, длина, ширина листьев растений, др. Например, у амаранта в растительной массе при снижении содержания клетчатки установлено повышение содержания жирового компонента, суммарного сахара и сохранение содержания каротина и белка, в семенах - увеличение содержания масла, сквалена, крахмала, белка, витамина С.

Experiments on application of hydrothermal nanosilica to increase productivity agricultural plants were carried out. Nanosilica sol was produced by ultrafiltration membrane concentration of orthosilicic acid polymers of hydrothermal solution to $\mathrm{SiO}_{2}$ content $10-20$ mas. \%. Plants treatment was done by diluted sol with $\mathrm{SiO}_{2}$ content in the range $0.0001-0.2$ mas. \%. Treatment of seeds ore upground parts of plants once ore twice was applied. $\mathrm{SiO}_{2}$ consumption was about 10-20 g per hectare. Experiments with wide range of plants was done, including potatoes, cabbage, vegetable marrow, onion, mustard, amaranth, tomato, sugar, wheat, beet and radish. Besides productivity biochemical and biometric parameters were changed: plants height, quantity, length, wide of leafs and others. For example, in upground mass of amaranth was detected decreasing of cellular tissue content and increasing grease, total saccharin content with constant content of carotene and protein. In amaranth seeds increasing of oil, squalene, starch, protein, vitamin C content was detected. 


\section{ВВЕДЕНИЕ}

Нанодисперсные кремнеземы под различными товарными знаками широко используются человеком многие десятилетия в фармпроизводствах получения таблетированных форм лекарств, как энтеросорбенты для связывания различных токсинов. Наноразмерный кремнезем под товарными знаками "Полисорб", "Аэросил" выпускается химической промышленностью в многотоннажных производствах для потребностей различных отраслей промышленности. Кремнезем является одним из приоритетных видов наноматериалов, используемых человеком во все возрастающих масштабах в составе пищевых продуктов и добавок, лекарственных препаратов и косметике и фармацевтике при разработке различных форм лекарственных препаратов на основе лекарственных растений.

Последние 20 лет в России активно развивается новое направление по получению и использованию нанодисперсного кремнезема гидротермального происхождения. В качестве сырья для получения нанодисперсного кремнезема используются жидкая фаза теплоносителя продуктивных скважин действующих гидротермальных электростан ${ }^{-}$ ций южной Камчатки (Мутновская ГеоэС, ВерхнеМутновская ГеоЭС). Применение современных методов мембранной ультрафильтрации позволило создать современную технологию производства стабильных водных золей нанокремнезема с низкой концентрацией примесей.

Актуальной проблемой в лекарственном растениеводстве является научный поиск путей повышения урожайности растений. В этом направлении несомненный интерес представляют вопросы по выявлению новых регуляторов роста растений для некорневой обработки растений, позволяющих получать экологически чистое и биологически ценное растительное сырье и продукцию. В связи с этим, поиск новых стимуляторов роста является актуальной задачей как лекарственного растениеводства, так и бионанотехнологии.

Действие на растения наночастиц (NP's) различного химического состава (нано- $\mathrm{SiO}_{2}, \mathrm{ZnO}, \mathrm{C}, \mathrm{Au}, \mathrm{Ag}$, $\mathrm{TiO}_{2}, \mathrm{~S}, \mathrm{Ge}, \mathrm{Ag}, \mathrm{Fe}_{2} \mathrm{O}_{3}, \mathrm{CeO}_{2}, \mathrm{CuO}$, др.) с высокой удельной поверхностью и химической активностью, диаметром пор, морфологией, уникальными физикохимическими характеристиками было изучено в большом количестве экспериментальных работ, обзор которых сделан в публикации [1]. Установлено существенное влияние наночастиц на рост и развитие растений: повышение скорости проростания семян, увеличение длины и диаметра корней, сокращение сроков появления ростков, увеличение высоты растений, увеличение биомассы, количества листьев и цветков, урожайности и др. Один из механизмов влияния наночастиц на эти показатели связывают с влиянием наночастиц, проникающих в клетки растений, на скорость фотосинтеза, эффективность использования растениями световой энергии. Углеродные нанотрубки можно направлять в хлоропласты клеток, увеличивая этим суммарное поглощение световой энергии, расширяя диапазон длин волн поглощения световой энергии в область ультрафиолета, зеленого света и около инфракрасного излучения [2, 3]. В частности, наночастицы $\mathrm{SiO}_{2}$ влияют на скорость фотосинтеза: 1) повышением активности ангидрата углерода и синтеза фотосинтетических пигментов (хлорофилла); 2) усилением фотолюминесцентных параметров хлорофилла, таких как активность потенциала PSII, скорость транспорта электронов, фотохимической эффективности [4, $5,6,7]$. Модифицированные наночастицы могут осуществлять транспорт веществ внутрь клетки (в том числе, транспорт ДНК) $[8,9]$, за счет чего открывается возможность манипуляции генами.

Концентрации наночастиц в водной среде, применяемой для обработки растений, зависят от химического состава и морфологии поверхности, культуры растений и находятся согласно данным работы [1], в пределах, указанных в табл.1.

Действие наночастиц $\mathrm{SiO}_{2}$ было испытано:

- на томате [4, 5] - ускорение прорастания семян, увеличение длины ростков (в три раза); стимулирование антиоксидантных свойств, накопления пролина, свободных аминокислот, питательных веществ при NaCl-стрессе (повышение толерантности к абиотическому стрессу);

- кукурузе (Zea mays L) [10] - повышение скорости проростания семян за счет улучшения доступности питательных веществ, изменения $\mathrm{pH}$ и проводимости среды роста;

- лиственнице (Changbai larch (Larixolgensis)) [11] - повышение скорости роста и качества семян, включая среднюю высоту, диаметр и длину главного корня, число корней семян, индуцирование синтеза хлорофилла, устойчивость к абиотическому стрессу при проращивании семян;

- салате [12] - повышение скорости проращивания семян;

- соевых бобах [13] (Glycine max) - повышение скорости прорастания семян регулированием содержания нитратов, повышением способности семян к адсорбции и усвоению воды и питательных веществ; 
Таблица 1. Пределы концентраций наночастиц в средах, применявшихся дяя обработки растений (по данным рабоmol [1])

Table 7. The concentration limits of nanoparticles in the media used for plant processing (according [7])

\begin{tabular}{|c|c|}
\hline $\begin{array}{l}\text { Химический состав } \\
\text { наночастиц } \\
\text { Chemical composi- } \\
\text { tion of nanoparticles }\end{array}$ & $\begin{array}{c}\text { Пределы концентраций нано- } \\
\text { частиц, применявщиеся для } \\
\text { o6работки растений, мacc. \% } \\
\text { Concentration limits used for } \\
\text { plant processing, mass. \% }\end{array}$ \\
\hline $\begin{array}{l}\text { Оксид графена } \\
\text { Graphene oxide }\end{array}$ & $0,04-0,08$ \\
\hline $\begin{array}{l}\text { Углеродные нано- } \\
\text { трубки (многостенные } \\
\text { и одностенные) } \\
\text { Carbon nanotubes } \\
\text { (multi-walled and } \\
\text { single-walled) }\end{array}$ & $0,0009-50$ \\
\hline $\mathrm{ZnO}$ & $0,0001-0,4$ \\
\hline Ge & $1-8$ \\
\hline $\mathrm{Ag}$ & $0,006-0,1$ \\
\hline$S$ & $0,0005-0,004$ \\
\hline $\mathrm{SiO}_{2}$ & 0,2-1,4 мас. \% = 2-14 г/л; 15 кг/га \\
\hline $\mathrm{TiO}_{2}$ & $0,005-0,25$ \\
\hline $\mathrm{Al}_{2} \mathrm{O}_{3}$ & $0,04-0,4$ \\
\hline Al & $0,001-0,03$ \\
\hline $\mathrm{Fe}_{2} \mathrm{O}_{3}$ & $0,05-0,075$ \\
\hline Оксид ZnFeCu & 0,005 \\
\hline $\mathrm{CeO}_{2}$ & 0,025 \\
\hline $\mathrm{CuO}$ & 0,05 \\
\hline $\mathrm{CO}_{3} \mathrm{O}_{4}$ & 0,5 \\
\hline $\begin{array}{l}\text { Гидроксиапатит } \\
\text { Hydroxyapatite }\end{array}$ & $0,01-0,2$ \\
\hline
\end{tabular}

- рисе [14] - повышение скорости роста корня за счет обработки наночастицами $\mathrm{SiO}_{2}$, поверхность которых была покрыта СdТе квантовыми точками (QD’s).

\section{Цель работы:}

1. выявление эффекта повышения урожайности для сельскохозяйственных растений обработкой гидротермальным нано- $\mathrm{SiO}_{2}$;

2. выявление наиболее эффективной концентрации $\mathrm{SiO}_{2}$ в водной среде, применяющейся для обработки растений;

3. выявления пределов изменения биохимических и биометрических показателей растений после обработки наночастицами $\mathrm{SiO}_{2}$.

\section{Получение золей нанокремнезема.}

Гидротермальные растворы содержат $\mathrm{SiO}_{2}$ за счет растворения алюмосиликатных минералов земной коры (ортоклаз, микроклин $\mathrm{K}\left(\mathrm{AlSi}_{3} \mathrm{O}_{8}\right)$, альбит $\mathrm{Na}\left(\mathrm{AlSi}_{3} \mathrm{O}_{8}\right)$, анортит $\mathrm{Ca}\left(\mathrm{Al}_{2} \mathrm{Si}_{2} \mathrm{O}_{8}\right)$, др.) и поликонденсации молекул ортокремниевой кислоты. В недрах в условиях повышенных давлений и температур в гидротермальных растворах образуются молекулы ортокремниевой кислоты (ОКК). После выхода раствора на поверхность давление и температура снижаются, раствор становится пересыщенным относительно растворимости аморфного кремнезема и в нем проходят гидролиз и поликонденсация молекул ОКК, приводящие к формированию сферических наночастиц $\mathrm{SiO}_{2}$ с диаметрами от 5-100 нм до 300-600 нм: $\mathrm{Si}_{\mathrm{m}} \mathrm{O}_{(\mathrm{m}-1)}(\mathrm{OH})_{(2 \mathrm{~m}+2)}+$ $\mathrm{Si}_{\mathrm{n}} \mathrm{O}_{(\mathrm{n}-1)}(\mathrm{OH})_{(2 \mathrm{n}+2)} \mathrm{Si}_{(\mathrm{m}+\mathrm{n})} \mathrm{O}_{(\mathrm{m}+\mathrm{n}-1)} \mathrm{OH}_{(2 \mathrm{n}+2 \mathrm{~m}+2)}+\mathrm{H}_{2} \mathrm{O}$.

Кроме кремнезема, в исходном растворе находятся другие компоненты, концентрации которых приведены в табл.2 [15, 16].

Поликонденсация молекул кремнекислоты проходит за счет конденсации силанольных групп с образованием силоксановых связей и частичной дегидратацией. Конечные размеры частиц кремнезема зависят в первую очередь от температуры и $\mathrm{pH}$, при которых проходит поликонденсация молекул ОКК. Повышение температуры поликонденсации и снижение $\mathrm{pH}$ приводят к увеличению конечных размеров

Таблица 2. Концентрация основных компонентов исходного гидротермального раствора, рН=9,2

Table 2. Concentrations of main components of initial hydrothermal solution, $\mathrm{pH}=9.2$

\begin{tabular}{|c|c|c|c|c|c|c|c|c|c|c|c|c|c|}
\hline $\begin{array}{l}\text { Компонент } \\
\text { Component }\end{array}$ & $\mathrm{Na}^{+}$ & $\mathrm{K}^{+}$ & $\mathrm{Li}^{+}$ & $\mathrm{Ca}^{2+}$ & $\mathrm{Mg}^{2+}$ & $\mathrm{Fe}^{2+, 3+}$ & $\mathrm{Al}^{3+}$ & $\mathrm{Cl}^{-}$ & $\mathrm{SO}_{4}{ }^{2}$ & $\mathrm{HCO}_{3}^{-}$ & $\mathrm{CO}_{3}{ }^{2-}$ & $\mathrm{H}_{3} \mathrm{BO}_{3}$ & $\mathrm{SiO}_{2}$ \\
\hline $\begin{array}{l}\text { Концентрация, } \\
\text { мг/дм }{ }^{3} \\
\text { Concentration, } \\
\text { mg/dm }{ }^{3}\end{array}$ & 282 & 48,1 & 1,5 & 2,8 & 4,7 & $<0,1$ & $<0,1$ & 251,8 & 220,9 & 45,2 & 61,8 & 91,8 & 780 \\
\hline
\end{tabular}




\section{NANOTECHNOLOGIES}

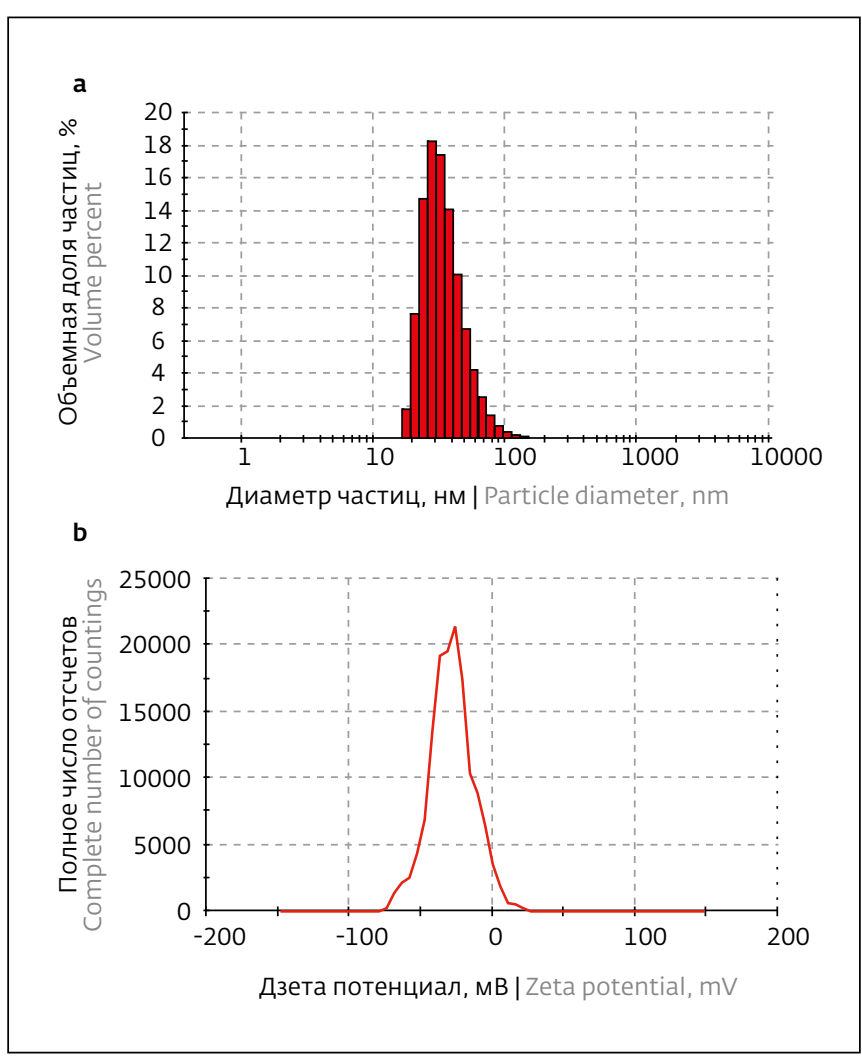

Рис.1. Размеры частиц и дзета-потенциал частиц в образце золя нанокремнезема: $а$ - гистограмма распределения размеров наночастии золя кремнезема; 6 - дзета-потенциал поверхности наночастиц золя

Fig.1. Particle sizes and zeta potential of particles in a nanosilica sol sample: $a$ - $a$ histogram of the distribution of silica sol nanoparticles sizes; $b$ - the zeta potential of the sol nanoparticles surface

частиц. На стадии поликонденсации температуру варьировали в пределах от 20 до $40^{\circ} \mathrm{C}$ (предварительным охлаждением в теплообменниках), $\mathrm{pH}=$ от 9,2. Концентрированные водные золи кремнезема получали из жидкой фазы гидротермальных растворов 3-ступенчатым ультрафильтрационным мембранным концентрированием: на 1-ой ступени содержание $\mathrm{SiO}_{2}$ в золе повышали от 0,05 до 0,3-0,4 мас. \%, на 2-ой ступени - до 10 мас. \%, на 3-ей - до 20-30 мас. \% и выше.

Ультрафильтрационные мембранные патроны капиллярного типа имели внутренний диаметр капилляров - 0,8 мм, площадь фильтрующей поверхности - 55 м², параметр минимальной отсекаемой массы частиц (mass weight cut off) MWCO = 50 кДа.

Распределение частиц золей по размерам определяли методом динамического светорассеяния, дзета-потенциал частиц - методом электрофореза. На рис.1 приведены результаты определений для одного из образцов золя, имевшего характеристики: плотность золя $\rho_{\mathrm{s}}=1080$ г/дм ${ }^{3}$, содержание $\mathrm{SiO}_{2}=$

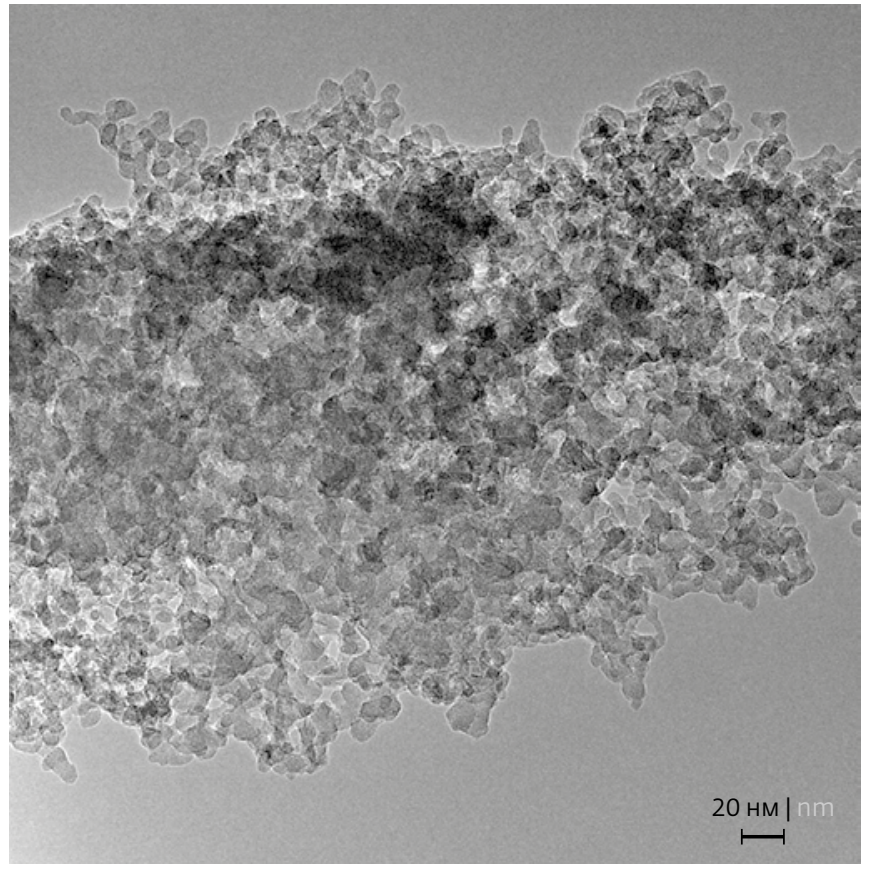

Рис. 2. ТЭМ-изображение наночастиц гидротермально$20 \mathrm{SiO}_{2}$. Удельная поверхность наночастии, определенная методом низкотемпературной адсорбции азота, $S_{\text {BET }}=410 \mathrm{~m}^{2} / 2$, coответствующий среднеповерхностный диаметр наночастии $\mathrm{SiO}_{2} d_{\text {BET }}=6,6$ нм. Исходное содер-

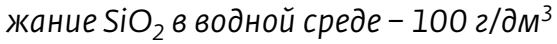

Fig.2. TEM image of hydrothermal $\mathrm{SiO}_{2}$ nanoparticles. The specific surface area of nanoparticles, determined by low-temperature nitrogen adsorption, $\mathrm{S}_{\mathrm{BET}}=410 \mathrm{~m}^{2} / \mathrm{g}$, the corresponding average surface diameter of $\mathrm{SiO}_{2}$ nanoparticles is $d_{\mathrm{BET}}=6.6 \mathrm{~nm}$. The initial $\mathrm{SiO}_{2}$ content in the aqueous medium is $100 \mathrm{~g} / \mathrm{dm}^{3}$

150 г/дм ${ }^{3}, \mathrm{pH}=8,6$, среднее значение диаметра частиц $\mathrm{SiO}_{2} \mathrm{~d}_{\mathrm{m}}=41,6$ нм, среднее значение дзета-потенциала поверхности частиц $\mathrm{SiO}_{2} \mathrm{x}_{\mathrm{m}}=-28,2 \mathrm{MB}$.

В табл.3 приведен диапазон характеристик золей $\mathrm{SiO}_{2}$, в котором могут варьироваться их значения с помощью предложенного подхода - ультрафильтрационного мембранного концентрирования гидротермального раствора.

Сферическая форма частиц $\mathrm{SiO}_{2}$ установлена методом туннельной электронной микроскопии (рис.2).

Удельная поверхность мезопористых порошков, получаемых криохимической вакуумной сублимацией золей $\mathrm{SiO}_{2}$ - от 50 до 500 м²/г, диаметр пор - 2-15 нм, поверхностная плотность силанольных групп - до 4,9 $\mathrm{Hм}^{-2}[15]$.

\section{Результаты экспериментов с сельскохозяйственными растениями}

Водную среду для обработки растений получали разбавлением гидротермального золя кремнезема 
Таблица 3. Физико-химические характеристики водных золей кремнезема, полученных ультрафильтрационным мембранным концентрированием

Table 3. Physical and chemical characteristics of aqueous silica sols produced by ultrafiltration membrane concentration

\begin{tabular}{|c|c|}
\hline $\begin{array}{l}\text { Характеристики } \\
\text { Characteristics }\end{array}$ & $\begin{array}{l}\text { Значения } \\
\text { Values }\end{array}$ \\
\hline $\mathrm{pH}$ & $8,0-9,2$ \\
\hline $\begin{array}{l}\text { Общее содержание } \mathrm{SiO}_{2} \text {, г/дм³ } \\
\text { Total content }\end{array}$ & $3,0-940,0$ \\
\hline $\begin{array}{l}\text { Плотность золя } \rho_{s}, \text { г/дм }{ }^{3} \\
\text { Sol density } \rho_{s}, g / \mathrm{dm}^{3}\end{array}$ & 1000-1510 \\
\hline $\begin{array}{l}\text { Средние значения диаметров нано- } \\
\text { частиц, нм } \\
\text { Average values of nanoparticle diam- } \\
\text { eters, nm }\end{array}$ & $5-100$ \\
\hline $\begin{array}{l}\text { Солесодержание TDS, мг/дм³ } \\
\text { Salt content }\end{array}$ & $800-2000$ \\
\hline $\begin{array}{l}\text { Удельная электропроводность } \sigma_{\mathrm{m}} \\
\text { мСм/см }\left(20^{\circ} \mathrm{C}\right) \\
\text { Efficient electroconductivity } \sigma_{\mathrm{m}}, \mathrm{mS} / \\
\mathrm{cm}\left(20^{\circ} \mathrm{C}\right)\end{array}$ & $0,8-1,56$ \\
\hline $\begin{array}{l}\text { Средние значения дзета-потенциала } \\
\text { ६ поверхности наночастиц, мB } \\
\text { Average values of zeta potential } \xi \text { of } \\
\text { the nanoparticle surfaces }\end{array}$ & $-25,0 \ldots-56,0$ \\
\hline $\begin{array}{l}\text { Динамическая вязкость } \eta, \\
\text { мПа.с }\left(20^{\circ} \mathrm{C}\right) \\
\text { Dynamical viscosity } \eta, \mathrm{mPa} \cdot \text { at }\left(20^{\circ} \mathrm{C}\right)\end{array}$ & $1,0-120,0$ \\
\hline $\begin{array}{l}\text { Содержание } \mathrm{SiO}_{2} \text { в веществе, осаж- } \\
\text { денном из золя, мac. \% } \\
\mathrm{SiO}_{2} \text { content in a substance deposited } \\
\text { from a sol, mass. \% }\end{array}$ & До ९९,72 \\
\hline
\end{tabular}

дистиллятом или водопроводной водой (в соответствии с требованиями Роспотребнадзора для питьевой воды) до достижения определенной концентрации $\mathrm{SiO}_{2}$, которую варьировали в пределах 0,0001-0,2 мас. \%: 0,0001, 0,001, 0,01, 0,1, 0,2 мас. \%. При концентрации $\mathrm{SiO}_{2}$ 0,005 мас. \% и объеме воды, применяемой для обработки - 300 л/га, суммарный расход $\mathrm{SiO}_{2}$ составлял 15 г/га. Такому расходу $\mathrm{SiO}_{2}$ соот- $^{-}$ ветствует определенное количество наночастиц $\mathrm{SiO}_{2}$, приходящихся на литр воды $\mathrm{N}_{\mathrm{pv}}$ (шт/л) и на 1 га обрабатываемой площади - $\mathrm{N}_{\mathrm{ph}}$ (шт/га):

$$
\begin{gathered}
\mathrm{N}_{\mathrm{pv}}=\mathrm{C}_{\mathrm{SiO}_{2}} /\left(\rho_{\mathrm{SiO}_{2}} \cdot \pi \mathrm{d}^{3} / 6\right), \\
\mathrm{N}_{\mathrm{ph}}=\mathrm{N}_{\mathrm{pv}} \cdot \mathrm{W}_{\mathrm{h}},
\end{gathered}
$$

Таблица 4. Количество наночастиц $\mathrm{SiO}_{2}$, приходящихся на питр воды $\mathrm{N}_{\text {pv }}($ uт./n) и на 1 га обрабатываемой ппощади - $N_{p h}\left(\right.$ (uт./2a), концентрации $\mathrm{SiO}_{2}$ в воде, равной 0,05 2/л $(0,005$ мас. \%), объема воды, применяемой для обработки - 300 n/2а, при различном среднекубическом диаметре наночастии

Table 4. The number of $\mathrm{SiO}_{2}$ nanoparticles per liter of water Npv (pcs/l) and per hectare of cultivated area - Nph (pcs/ha), the concentration of $\mathrm{SiO}_{2}$ in water equal to $0.05 \mathrm{~g} / \mathrm{l}(0.005$ mass. \%), the volume of water, used for processing of $300 \mathrm{l} / \mathrm{ha}$, with different

\begin{tabular}{|c|c|c|}
\hline $\begin{array}{c}\mathrm{d}_{\mathrm{n}} \mathrm{HM} \\
\mathrm{mm}\end{array}$ & 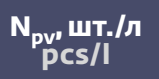 & $\mathrm{N}_{\mathrm{ph}}$, WT///ra \\
\hline 5 & $4,34 \cdot 10^{19}$ & $1,3 \cdot 10^{22}$ \\
\hline 10 & $5,425 \cdot 10^{18}$ & $1,625 \cdot 10^{21}$ \\
\hline 20 & $6,78 \cdot 10^{17}$ & $2,03 \cdot 10^{20}$ \\
\hline 30 & $2,0 \cdot 10^{17}$ & $6,0 \cdot 10^{19}$ \\
\hline 40 & $6,33 \cdot 0^{16}$ & $1,9 \cdot 10^{19}$ \\
\hline 50 & $3,24 \cdot 10^{16}$ & $0,97 \cdot 10^{19}$ \\
\hline 60 & $1,87 \cdot 10^{16}$ & $5,63 \cdot 10^{18}$ \\
\hline 70 & $1,18 \cdot 10^{16}$ & $3,54 \cdot 10^{18}$ \\
\hline 80 & $0,79 \cdot 10^{16}$ & $2,37 \cdot 10^{18}$ \\
\hline 90 & $5,55 \cdot 10^{15}$ & $1,66 \cdot 10^{18}$ \\
\hline 100 & $5,42 \cdot 10^{15}$ & $1,62 \cdot 10^{18}$ \\
\hline
\end{tabular}
average cubic diameters of nanoparticles

где $\mathrm{C}_{\mathrm{SiO2}}$ - концентрация $\mathrm{SiO}_{2}$, равная 0,05 г/л (0,005 мас. \%), $\rho_{\mathrm{SiO}_{2}}$ - плотность $\mathrm{SiO}_{2}, 2,2$ г/см³, $\mathrm{d}$ - среднекубический диаметр наночастиц, $\mathrm{cm}, \mathrm{W}_{\mathrm{h}}$ - объем воды для обработки 1 га, 300 л/га.

Согласно уравнениям (1) и (2) количество наночастиц $\mathrm{SiO}_{2}$ в единице объема воды, применяемой для обработки, и количество частиц, приходящееся на единицу обрабатываемой площади обратно пропорционально размеру частиц $\mathrm{d}$ в третьей степени и прямо пропорционально концентрации $\mathrm{C}_{\mathrm{SiO}_{2}}$ в воде (табл.4).

В табл.5 представлены полученные нами результаты 2016-2019 годов повышения урожайности и других показателей для сельскохозяйственных растений в соответствии 
Таблица 5. Результаты экспериментов по обработке сельскохозяйственных растений водной нанодисперсией, содержащей наночастицы $\mathrm{SiO}_{2}$. $\left[\mathrm{SiO}_{2}\right]$ - общее содержание $\mathrm{SiO}_{2}$ в водной среде, применяемой для обработки растений, при которой достигнут максим прироста урожайности относительно контроля. (-) - показатели не определяли

Table 5. The results of experiments on the treatment of agricultural plants with aqueous nanodispersion containing $\mathrm{SiO}_{2}$ nanoparticles. $\left[\mathrm{SiO}_{2}\right]$ is the total $\mathrm{SiO}_{2}$ content in the aquatic environment used for treating plants at which the yield growth relative to the control is maximized. (-)-indicators were not determined

\begin{tabular}{|c|c|c|c|c|}
\hline $\begin{array}{l}\text { Культура сельско- } \\
\text { хозяйстенного } \\
\text { растения } \\
\text { Crop plant }\end{array}$ & $\begin{array}{l}{\left[\mathrm{SiO}_{2}\right]} \\
\text { Macc. } \% \\
\text { mass. \% }\end{array}$ & $\begin{array}{c}\text { Прирост } \\
\text { урожайности, } \\
\% \\
\text { Yield } \\
\text { increase, \% }\end{array}$ & $\begin{array}{c}\text { Прирост биохими- } \\
\text { ческих показателей } \\
\text { растений,\% } \\
\text { The increase in bio- } \\
\text { chemical parameters } \\
\text { of plants, \% }\end{array}$ & $\begin{array}{c}\text { Прирост биометрических } \\
\text { показателей растений,\% } \\
\text { The growth of biometric indicators } \\
\text { of plants, \% }\end{array}$ \\
\hline $\begin{array}{l}\text { Картофель } \\
\text { Potato }\end{array}$ & 0,2 & 30 & - & - \\
\hline $\begin{array}{l}\text { Капуста индау } \\
\text { посевной Покер } \\
\text { Cabbage Indau } \\
\text { Sowing } \\
\text { Poker }\end{array}$ & 0,005 & 34,4 & - & $\begin{array}{l}\text { Высота розетки листьев - 5,2; диаметр розетки } \\
\text { листьев - 6,4; число листьев-17; длина листо- } \\
\text { вой пластинки - 5,2; ширина листовой пла- } \\
\text { стинки - 22; масса одного растения - 55,8 } \\
\text { The height of the leaf outlet is 5.2; diameter of } \\
\text { the leaf outlet - } 6.4 \text {; the number of leaves - } 17 \text {; the } \\
\text { length of the leaf blade is } 5.2 ; \text { the width of the leaf } \\
\text { blade is } 22 ; \text { the mass of one plant is } 55.8\end{array}$ \\
\hline $\begin{array}{l}\text { Капуста кресс-салат } \\
\text { Дукат } \\
\text { Cabbage watercress } \\
\text { Ducat }\end{array}$ & 0,005 & 38,5 & - & $\begin{array}{l}\text { Высота розетки листьев - 15,1; диаметр розетки } \\
\text { листьев - 8,8; число листьев - 16,4; длина листо- } \\
\text { вой пластинки - 18,6; ширина листовой пла- } \\
\text { стинки - 18,1; масса одного растения - } 34,9 \\
\text { The height of the leaf outlet is } 15.1 \text {; the diameter of } \\
\text { the leaf rosette - 8.8; the number of leaves }-16.4 ; \\
\text { the length of the leaf blade is } 18.6 \text {; the width of the } \\
\text { leaf blade is 18.1; the mass of one plant is } 34.9\end{array}$ \\
\hline $\begin{array}{l}\text { Горчица сарептская } \\
\text { Mустанг } \\
\text { Mustard mustard } \\
\text { mustang }\end{array}$ & 0,005 & 53,2 & - & $\begin{array}{l}\text { Высота розетки листьев - 34; диаметр розетки } \\
\text { листьев - 34,4; число листьев-76,5; длина } \\
\text { листовой пластинки - 13,2; ширина листовой } \\
\text { пластинки - 76,7; масса одного растения - } 52,6 \\
\text { The height of the leaf outlet is } 34 \text {; diameter of the } \\
\text { leaf rosette - 34.4; the number of leaves - } 76.5 \text {; the } \\
\text { length of the leaf blade is } 13.2 \text {; the width of the leaf } \\
\text { blade is } 76.7 \text {; the mass of one plant is } 52.6\end{array}$ \\
\hline $\begin{array}{l}\text { Горчица сарептская } \\
\text { Мей Лин } \\
\text { Mustard Sarepta } \\
\text { Mei Lin }\end{array}$ & 0,005 & 35,7 & - & $\begin{array}{l}\text { Высота розетки листьев - 14; диаметр розетки } \\
\text { листьев - 10,5; число листьев-19,5; длина } \\
\text { листовой пластинки - } 7,3 \text {; ширина листовой пла- } \\
\text { стинки - 11,3; масса одного растения - } 21,5 \\
\text { The height of the leaf outlet is } 14 \text {; diameter of the } \\
\text { leaf rosette - } 10.5 \text {; the number of leaves }-19.5 \text {; the } \\
\text { length of the leaf blade is } 7.3 \text {; the width of the leaf } \\
\text { blade is 11.3; the mass of one plant is } 21.5\end{array}$ \\
\hline $\begin{array}{l}\text { Кабачок гибрид } \\
\text { Белогор Fl } \\
\text { Zucchini hybrid } \\
\text { Belogor Fl }\end{array}$ & 0,001 & 59,8 & $\begin{array}{l}\text { Сухое вещество - 33; } \\
\text { сахар - 50,2; витамин } \\
\text { С-19,7; пектин - 34,5; } \\
\text { нитраты - (-) 22,7 } \\
\text { dry matter - 33; } \\
\text { sugar }-50.2 ; \text { vitamin } \\
\text { C- } 19.7 ; \text { pectin }-34.5 ; \\
\text { nitrates }-(-) 22.7\end{array}$ & - \\
\hline
\end{tabular}




\begin{tabular}{|c|c|c|c|c|}
\hline $\begin{array}{l}\text { Культура сельско- } \\
\text { хозяйственного } \\
\text { растения } \\
\text { Crop plant }\end{array}$ & $\begin{array}{l}{\left[\mathrm{SiO}_{2}\right]} \\
\text { macc. \% } \\
\text { mass. \% }\end{array}$ & $\begin{array}{c}\text { Прирост } \\
\text { урожайности, } \\
\% \\
\text { Yield } \\
\text { increase, \% }\end{array}$ & $\begin{array}{c}\text { Прирост биохими- } \\
\text { ческих показателей } \\
\text { растений, \% } \\
\text { The increase in bio- } \\
\text { chemical parameters } \\
\text { of plants, \% }\end{array}$ & $\begin{array}{c}\text { Прирост биометрических } \\
\text { nokasaтелей растений,\% } \\
\text { The growth of biometric indicators } \\
\text { of plants, \% }\end{array}$ \\
\hline $\begin{array}{l}\text { Лук-слизун сорта } \\
\text { Грин } \\
\text { Green Slime Onions }\end{array}$ & 0,005 & 17,0 & - & $\begin{array}{l}\text { Высота растения - 17,8; число листьев - 25,2; } \\
\text { ширина листа - 22,7; длина листа - } 16,4 \\
\text { Plant height - 17.8; the number of leaves - 25.2; } \\
\text { sheet width - 22.7; sheet length - } 16.4\end{array}$ \\
\hline $\begin{array}{l}\text { Амарант } \\
\text { Amaranth }\end{array}$ & 0,001 & $\begin{array}{l}\text { Растительная } \\
\text { масса - 25; } \\
\text { семена -68 } \\
\text { Plant } \\
\text { mass-25; } \\
\text { seeds - } 68\end{array}$ & 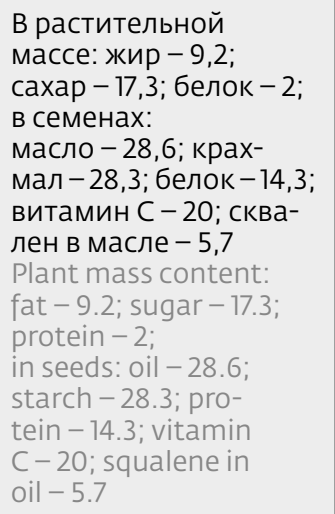 & - \\
\hline $\begin{array}{l}\text { Томат (при заболе- } \\
\text { вании мучнистой } \\
\text { pocoй) } \\
\text { Tomato (with pow- } \\
\text { dery mildew disease) }\end{array}$ & 0,05 & 30 & - & - \\
\hline $\begin{array}{l}\text { Яровая пшеница } \\
\text { Spring wheat }\end{array}$ & 0,02 & 13,8 & - & $\begin{array}{l}\text { Энергия проростания семян -2,6; лабораторная } \\
\text { всхожесть семян - 3,2; сила роста семян -6,8; } \\
\text { морфологические параметры: длина главного } \\
\text { корня-3,1; число корней - 6,2; полевая всхо- } \\
\text { жесть- } 3,4 \text {; степень полегания - 1-2 балла } \\
\text { Seed germination energy -2.6; laboratory ger- } \\
\text { mination of seeds - 3.2; seed growth force - } 6.8 ; \\
\text { morphological parameters: Iength of the main } \\
\text { root - 3.1; the number of roots is } 6.2 \text {; field germina- } \\
\text { tion - 3.4; the degree of lodging - } 1-2 \text { points }\end{array}$ \\
\hline $\begin{array}{l}\text { Сахарная свекла } \\
\text { Sugar beet }\end{array}$ & 0,02 & 9,9 & $\begin{array}{l}\text { Сахаристость - 1,3 } \\
\text { Sugar content }-1.3\end{array}$ & - \\
\hline $\begin{array}{l}\text { Редис Меркадо } \\
\text { Radish Mercado }\end{array}$ & 0,005 & 9,1 & - & $\begin{array}{l}\text { Высота растения - (-) } 10 \text {; число листьев }-2 \text {; } \\
\text { масса надземной части }-12,5 \\
\text { Plant height }-(-) 10 \text {; number of leaves }-2 \text {; the mass } \\
\text { of the aboveground part is } 12.5\end{array}$ \\
\hline
\end{tabular}




\begin{tabular}{|c|c|c|c|c|}
\hline $\begin{array}{l}\text { Культура сельско- } \\
\text { хозяйственного } \\
\text { растения } \\
\text { Crop plant }\end{array}$ & $\begin{array}{l}{\left[\mathrm{SiO}_{2}\right]} \\
\text { Macc. } \% \\
\text { mass. \% }\end{array}$ & $\begin{array}{c}\text { Прирост } \\
\text { урожайности, } \\
\% \\
\text { Yield } \\
\text { increase, \% }\end{array}$ & $\begin{array}{c}\text { Прирост биохими- } \\
\text { ческих показателей } \\
\text { растений, \% } \\
\text { The increase in bio- } \\
\text { chemical parameters } \\
\text { of plants, \% }\end{array}$ & $\begin{array}{c}\text { Прирост биометрических } \\
\text { показателей растений,\% } \\
\text { The growth of biometric indicators } \\
\text { of plants, \% }\end{array}$ \\
\hline $\begin{array}{l}\text { Редис Кармен*" } \\
\text { Radish Carmen * }\end{array}$ & 0,005 & 38,9 & - & $\begin{array}{l}\text { Высота растения - } 1,3 \text {; число листьев - (-) 5,3; } \\
\text { масса надземной части - (-) } 20 \\
\text { Plant height }-1.3 \text {; the number of leaves - (-) 5.3; } \\
\text { the mass of the aboveground part - (-) } 20\end{array}$ \\
\hline $\begin{array}{l}\text { Салат листовой } \\
\text { сорта Балет } \\
\text { Lettuce of sheet } \\
\text { variety Ballet }\end{array}$ & $\begin{array}{l}0,005 \\
\mathrm{HaHo} \mathrm{SiO}_{2} \\
+0,045 \\
\text { крезацин } \\
0.005 \\
\text { nano-SiO } \\
+0.045 \\
\text { crezacin }\end{array}$ & 26,4 & 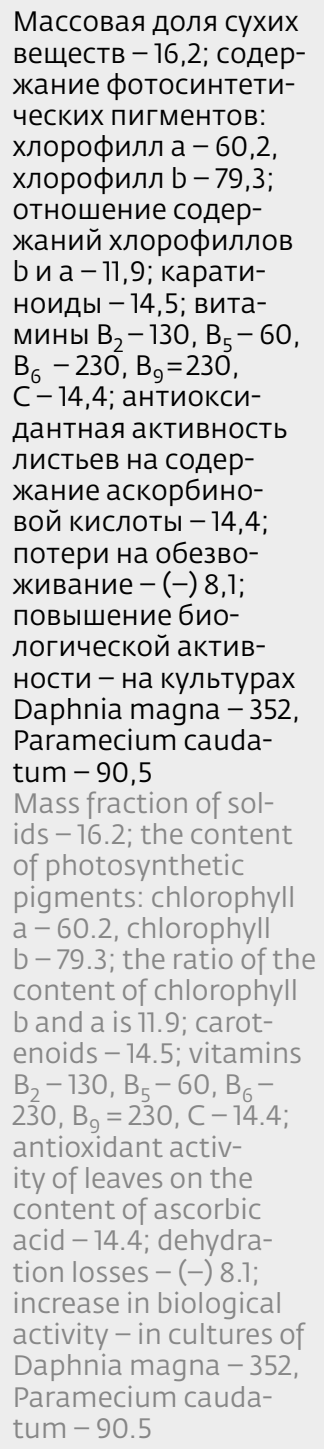 & $\begin{array}{l}\text { Высота растений - } 8 \text {; средняя масса надземной } \\
\text { части - } 26,4 \\
\text { Plant height }-8 \text {; the average mass of the aerial part } \\
\text { is } 26.4\end{array}$ \\
\hline
\end{tabular}

В условиях гидропонной культуры на субстрате из минеральной ваты; выращивание в фитотроне ИсР-0.1 с освещением из светодиодных (красных и синих, 40 Вт) и люминисцентных светильников (60 Вт); суммарная интенсивность излучения (плотность потока фотонов) $\mathrm{N}_{\mathrm{q}}-$

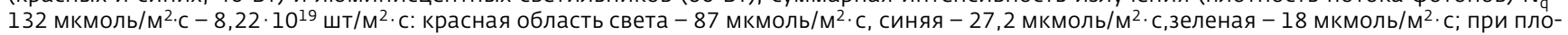
щади полки в фитотроне 0,322 м² плотность потока фотонов на площадь полки составляет 2,646 $10^{19}$ шт./с; при диаметре наночастиц SiO 2 40 нм их количество, соответствующее площади полки - 0,42 $10^{15}$ шт. / in a hydroponic culture on a mineral wool substrate; growing in the ISR-0.1 phytotron with LED lighting (red and blue, $40 \mathrm{~W}$ ) and fluorescent lamps (60 W); total radiation intensity (photon flux density) $\mathrm{Nq}-132 \mu \mathrm{mol} / \mathrm{m}^{2} \cdot \mathrm{s}-$ $8.22 \cdot 10^{19} \mathrm{pcs} / \mathrm{m}^{2} \cdot \mathrm{s}$ : red light $-87 \mu \mathrm{mol} / \mathrm{m}^{2} \cdot \mathrm{s}$, blue $-27.2 \mu \mathrm{mol} / \mathrm{m}^{2} \cdot \mathrm{s}$, green $-18 \mu \mathrm{mol} / \mathrm{m}^{2} \cdot \mathrm{s}$; when the shelf area in the phytotron is $0.322 \mathrm{~m}{ }^{2}$, the photon flux density per shelf area is $2.646 \cdot 10^{19} \mathrm{pcs} / \mathrm{s}$; when the diameter of $\mathrm{SiO}_{2}$ nanoparticles is $40 \mathrm{~nm}$, their number corresponding to the shelf area is $0.42 \cdot 10^{15} \mathrm{pCS}$ 


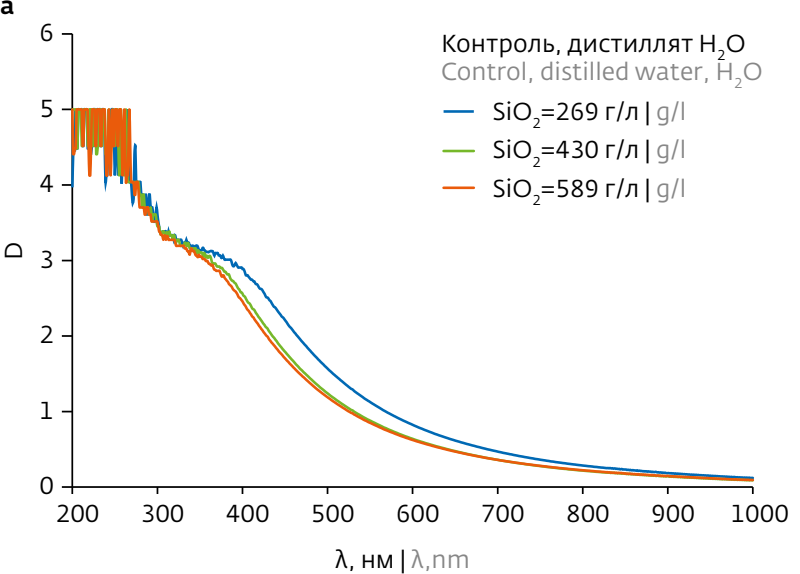

c

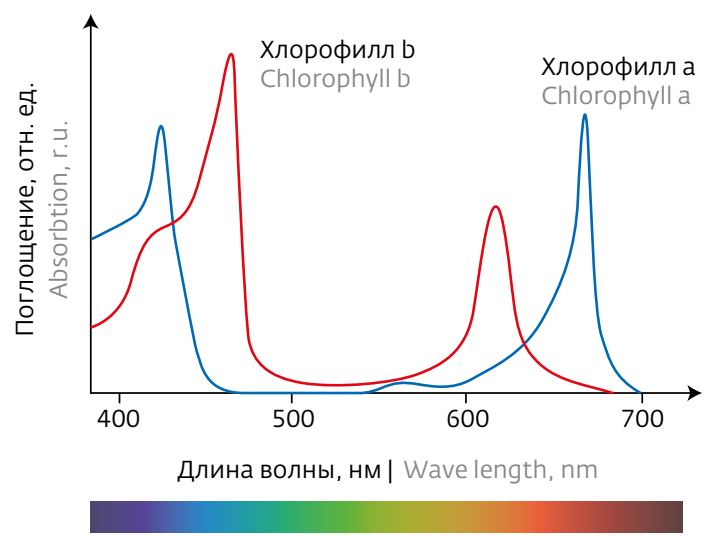

b

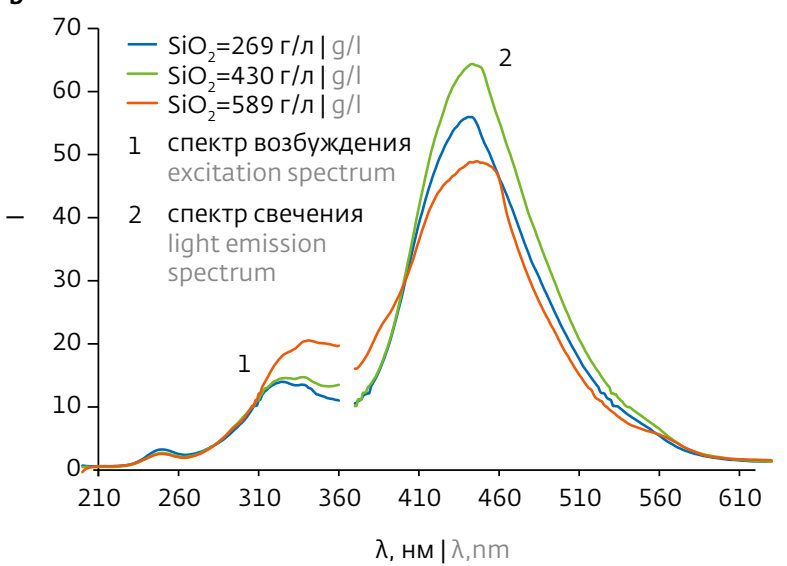

d

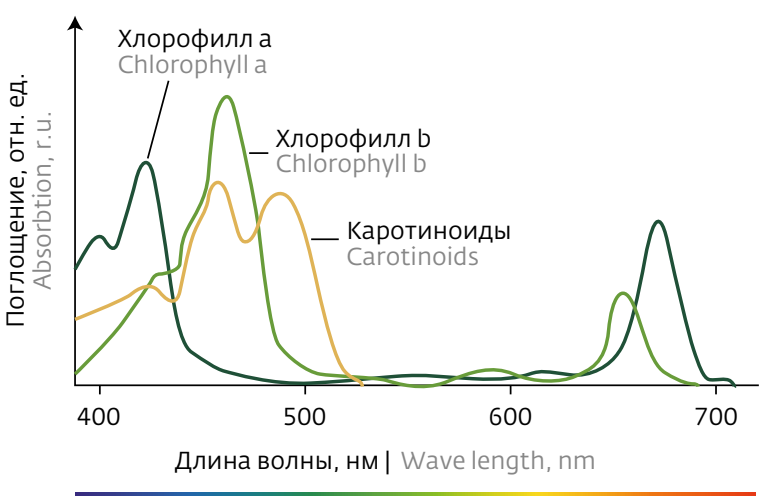

Рис.3. Оптические свойства золя гидротермального нанокремнезема, хлорофиляов $a$ и $b$, каратиноидов.

$a$ - оптическая плотность золей гидротермального нанокремнезема с различным содержанием $\mathrm{SiO}_{2}$;

b - спектр пюминесценции золей гидротермального нанокремнезема с различным содержанием $\mathrm{SiO}_{2}: a-$ спектр возбуждения; $b$ - спектр пюминесценции;

c-характерные спектры поглощения электромагнитного излучения хпорофилпов а и $b$;

$d$-характерные спектры поглощения хлорофиллов а и ь и каратиноидов

Fig.3. Optical properties of a sol of hydrothermal nanosilica, chlorophyll $a$ and $b$, carotenoids.

$a$ - optical density of hydrothermal nanosilica sols with different $\mathrm{SiO}_{2}$ content;

$b$ - luminescence spectrum of sols of hydrothermal nanosilica with different $\mathrm{SiO}_{2}$ contents: $a$ - excitation spectrum; $b$ - luminescence spectrum;

$c$ - the characteristic absorption spectra of the electromagnetic radiation of chlorophylls $a$ and $b$;

$d$-characteristic absorption spectra of chlorophylls $a$ and $b$ and carotenoids

с применяемыми нами биотехнологическими подходами некорневой обработки растений наночастицами гидротермального кремнезема в различные вегетативные фазы их развития [17-32].

На рис. 3 сопоставлены спектры оптического поглощения и люминисценции золей гидротермального нанокремнезема и спектры поглощения электромагнитного излучения (ЭМИ) для хлорофиллов $\mathrm{a}$ и $\mathrm{b}$ и для каратиноидов. Максимальные значения оптической плотности золей $\mathrm{SiO}_{2}$ приходится на длины волн 350-550 нм (рис.3а). В спектре возбуждения при изучении люминесценции наночастицы $\mathrm{SiO}_{2}$ в водной среде активное поглощение Эми наблюдалось в невидимой 
ультрафиолетовой области с максимумом при длинах волн 320-340 нм (рис.3b). При этом наночастицы $\mathrm{SiO}_{2}$ переизлучают ЭМИ в режиме люминесценции при длинах волн в синей видимой области с максимумом 430450 нм. Активная люминисценция наночастиц $\mathrm{SiO}_{2}$ наблюдается в области от 410 до 510 нм. В этом диапазоне длин волн находятся левые максимумы спектров поглощения хлорофиллов a и b (рис.3c). В диапазоне длин волн 410-510 нм находится почти весь спектр поглощения каратиноидов (рис.3d). С учетом этого наночастицы $\mathrm{SiO}_{2}$ могут люминисценцией увеличивать количество квантов света, поглощаемых хлорофиллами a и b и каратиноидами. Это перераспределение световой энергии можно усилить, если модифицировать поверхность наночастиц $\mathrm{SiO}_{2}$ металлами или полупроводниками.

\section{Выводы}

1. Приведены обобщения по проведенным экспериментальным работам 2016-2019 годов обработки семян и (или) некорневой обработки растений по листу с применением концентратов золей наночастиц $\mathrm{SiO}_{2}$ гидротермального происхождения в пределах от 9 до 60\%. Впервые показана возможность повышения показателей фотосинтеза, урожайности растений с применением новых биотехнологических подходов с применением наночастиц гидротермального происхождения. При повышении урожайности растений одновременно достигается повышение биохимических и биометрических показателей растений и увеличение показателей фотосинтеза.

2. Приросты урожайности растений, их биохимических и биометрических показателей зависят от содержания $\mathrm{SiO}_{2}$ в водной среде, применяемой для обработки, и одновременно достигают максимума при определенном значении содержания $\mathrm{SiO}_{2}$ : для большинства культур растений от 0,01 до 0,005 мас. \%.

3. Количественно прирост биохимических и биометрических показателей растений в большинстве случаев коррелирует с приростом урожайности. В случае горчицы сарептской Мустанг обработка наночастицами $\mathrm{SiO}_{2}$ привела к изменению формы листовой пластинки: при приросте урожайности 53,2\% прирост ширины листовой пластинки $(76,7 \%)$ был непропорционален и значительно больше по сравнению с приростом длины листовой пластинки $(13,2 \%)$.

4. Значительное повышение содержания сахара после обработки кабачка гибрида Белогор F1 $(50,2 \%)$ и амаранта $(17,3 \%$ в растительной массе) показывает интенсификацию фотосинтеза, которая происходит за счет поступления наночастиц $\mathrm{SiO}_{2}$ в клетки растений.

5. Наиболее убедительным свидетельством интенсификации фотосинтеза после обработки растений наночастицами $\mathrm{SiO}_{2}$ следует считать данные по приросту содержания фотосинтетических пигментов и каратиноидов в салате листовом сорта "Балет", выращенном в фитотроне модели ИСР 0.1 при исключении множества неучитываемых факторов влияния внешней среды, присущей вегетации растений в открытом грунте и больших теплицах. Увеличение фотосинтетических пигментов составило: хлорофилл а - 60,2\%, хлорофилл b - 79,3\%; отношение содержаний хлорофиллов b и а увеличилось на 11,9\%; содержание каратиноидов увеличилось - 11,9\%.

\section{ЛИТЕРАТУPA / REFERENCES}

1. Manzer H. Siddiqui, Mohamed H. Al-Whaibi, Mohammad Firoz and Mutahhar Y. Al-Khaishany. Role of Nanoparticles in Plants. In book: Nanotechnology and Plant Sciences. Springer International Publishing Switzerland. 2015. P. 19-35.

2. Cossins D. (2014) Next generation: nanoparticles augment plant functions. The incorporation of synthetic nanoparticles into plants can enhance photosynthesis and transform leaves into biochemical sensors. The scientist, news \& opinion, March16. http://www.the-scientist.com/articles. view/ article No /39440 /title/ Next-Generation-NanoparticlesAugment-Plant-Functions.

3. Giraldo J.P., Landry M.P., Faltermeier S.M., McNicholas T.P., Iverson N.M., Boghossian A.A., Reuel N.F., Hilmer A.J., Sen F., Brew J.A., Strano M.S. (2014) Plant nanobionics approach to augment photosynthesis and biochemical sensing. Nat Mater. doi:10.1038/ nmat3890.

4. Siddiqui M.H., Al-Whaibi M.H. (2014) Role of nano- $\mathrm{SiO}_{2}$ in germination of tomato (Lycopersicum esculentum seeds Mill.). Saudi Biol Sci 21:13-17.

5. Siddiqui M.H., Al-Whaibi M.H., Faisal M., Al Sahli A.A. (2014) Nano-silicon dioxide mit- 
igates the adverse effects of salt stress on Cucurbita pepo L. Environ Toxicol Chem 33(11):2429-2437. doi:10.1002/etc. 2697.

6. Xie Y., Li B., Zhang Q., Zhang C. (2012) Effects of nano-silicon dioxide on photosynthetic fluorescence characteristics of Indocalamus barbatus McClure. J Nanjing Forest Univ (Natural Science Edition) 2:59-63.

7. Xie Y., Li B., Zhang Q., Zhang C., Lu K., Tao G. (2011) Effects of nano-TiO2 on photosynthetic characteristics of Indocalamus barbatus. J Northeast For Univ 39:22-25.

8. Galbraith D.W. (2007) Nanobiotechnology: silica breaks through in plants. Nat Nanotechnol 2:272-273

9. Torney F., Trewyn B.G., Lin V.S., Wang K. (2007) Mesoporous silica nanoparticles deliver DNA and chemicals into plants. Nat Nanotechnol 2:295-300.

10. Suriyaprabha R., Karunakaran G., Yuvakkumar R., Rajendran V., Kannan N. (2012) Silica nanoparticles for increased silica availability in maize (Zea mays L) seeds under hydroponic conditions.

11. Bao-shan L., Shao-qi D., Chun-hui L., Lijun F., Shu-chun Q., Min Y. (2004) Effect of TMS (nanostructured silicon dioxide) on growth of Changbai larch seedlings. J Forest Res 15:138-140.

12. Shah V., Belozerova I. (2009) Influence of metal nanoparticles on the soil microbial community and germination of lettuce seeds. Water Air Soil Pollut 197:143-148.

13. Lu C.M., Zhang C.Y., Wen J.Q., Wu G.R., Tao M.X. (2002) Research on the effect of nanometer materials on germination and growth enhancement of Glycine max and its mechanism. Soybean Sci. 21:68-172.

14. Wang A., Zheng Y., Peng F. (2014) Thickness-controllable silica coating of CdTe QDs by reverse Microemulsion method for the application in the growth of rice. J Spectrosc. http://dx.doi.org/10.1155/2014/169245.

15. Потапов В.В., Сердан А.А., Кашпура В.Н., Горвев Д.С. Получение и свойства нанокремнезема на основе гидротермального раствора // Химическая технология. 2017. № 2. C. 65-73.

16. Зеленков В.Н., Потапов В.В. Биологическая активность соединений кремния. Часть 2. Аморфные наноразмерные кремнеземы: химико-технологическая аспекты получения, применения и перспективы использования гидротермальных источников (обзор литературы) // Вестник Российской Академии Естественных Наук. 2018. № 1 . С. 41-50.

17. Патент РФ на изобретение. Алексеева К.Л., Зеленков В.Н., Потапов В.В. Способ борьбы с мучнистой росой томатов в теплицах. Патент РФ на изобретение № 2646058. Дата приоритета - 06 июля 2017.

18. Петриченко В.Н., Зеленков В.Н., Потапов В.В. Влияние наночастиц гидротермального кремнезема на урожайность кабачка в условиях Ростовской области // Сборник трудов Международной научнопрактической конференции, посвященной VII Квасниковским чтениям, "Селекция, семеноводство и сортовая агротехника овощных, бахчевых и цветочных культур", 1 декабря, 2016 г. Рязань: ГУП РО "Рязанская областная типография". 2016. С. 225227.

19. Зеленков В.Н., Петриченко В.Н., Потапов В.В., Карпачев В.В., Воропаева Н. Л., Лапин А.А. Испытание гидротермального нанокремнезема привнекорневой обработке вегетирующих растений амаранта // Сборник тезисов докладов Шестой Международной конференции "От наноструктур, наноматериалов, нанотехнологий к наноиндустрии", Россия, Ижевск, 4-6 апреля 2017. Ижевск: издательство ИжГТУ им. М.Т. Калашникова. 2017. С. 186-189.

20. Зеленков В.Н., Иванова М.И., Петриченко В.Н., Потапов В.В. Фотосинтетическая и биологическая продуктивность брокколи и качество кабачков при внекорневой обработке растений наночастицами кремнезема гидротермального происхождения // Сборник материалов XII Международного симпозиума "Новые и нетрадиционные растения и перспективы их использования", 19-23 июня 2017, Пущино. М.: Издательство российского университета дружбы народов. 2017. C. $125-127$.

21. Зеленков В.Н., Петриченко В.Н., Потапов В.В., Логинов С.В. Использование наноразмерных структур кремнезема гидротермального происхождения и кремнийорганических препаратов нового поколения для получения продукции на основе топинамбура и амаранта нового качества // Сборник материалов XII Международного 
симпозиума "Новые и нетрадиционные растения и перспективы их использования", 19-23 июня 2017, Пущино. - М.: Издательство российского университета дружбы народов, 2017. C. 216-218.

22. Зеленков В.Н., Алексеева К.Л., Потапов В.В., Воропаева Н.Л., Карпачев В.В. Водные золи гидротермального нанокремнезема и защита растений томата от мучнистой росы при внекорневой обработке // Сборник тезисов VIII ежегодной конференции Нанотехнологического общества России, Москва 31.03.2017. С. 184-187.

23. Потапов В.В., Сивашенко В.А., Зленков В.Н., Воропаевна Н.Л., Карпачев В.В. Водные золи и порошки нанокремнезема и продуктивность картофеля // Сборник тезисов VIII ежегодной конференции Нанотехнологического общества России, Москва 31.03.2017. С. 188-190.

24. Зеленков В.Н., Иванова М.И., Потапов В.В., Бухаров А.Ф., Литнецкий А.В. Воропаева Н.Л., Карпачев В.В. Гидротермальный нанокремнезем, горчица сарептская, внекорневая обработка, урожайность // Сборник тезисов VIII ежегодной конференции Нанотехнологического общества России, Москва 31.03.2017. C. 197-199.

25. Зеленков В.Н., Петриченко В.Н., Иванова М.И., Потапов В.В. Гидротермальный нанокремнезем и его влияние на продуктивность кабачка и зеленых капустных культур привнекорневой обработке растений // Актуальная биотехнология. 2017. № 2(21). Материалы V Международной научно-практической конференции "Биотехнология: наука и практика". С. 98-100.

26. Костин В.И., Зеленков В.Н., Потапов В.В., Решетникова В.Н. Использование нанодисперсного кремнезема гидротермального происхождения в технологии выращивания яровой пшеницы и сахарной свеклы // Сборник научных трудов РАЕН "Нетрадиционные природные ресурсы, инновационные технологии и продукты". - М. : РАЕН, 2017. С. 11-19.

27. Зеленков В.Н., Иванова М.И., Потапов В.В., Бухаров А.Ф., Литнецкий А.В. Биологически активное действие гидротермального нанокремнезема при некорневой обработке лука-слизуна (ALLIUM NUTANTS L.) // Сборник научных трудов РАЕН "Нетрадиционные природные ресурсы, инновационные технологии и продукты". - М. : РАЕН, 2017. С. 51-56.
28. Зеленков В.Н., Иванова М.И., Потапов В.В., Литнецкий А.В. Гидротермальный нанокремнезем в технологии выращивания индау посевного // Сборник научных трудов РАЕН "Нетрадиционные природные ресурсы, инновационные технологии и продукты". - М.: РАЕН, 2017. С. 56-63.

29. Зеленков В.Н., Петриченко В.Н., Потапов В.В., Елисеева Л.Г., Иванова М.И., Латушкин В.В., Новиков В.Б. Проверка комплексного препарата гидротермального нанокремнезема с крезационом для гидропонного выращивания салата листового в замкнутой системе фитотрона ИСР-1 // Актуальная биотехнология. 2018. № 3 (26). С. 378-382.

30. Зеленков В.Н., Иванова М.И., Потапов В.В., Литнецкий А.В. Опыт применения гидротермального нанокремнезема в технологии выращивания редиса в условиях открытого грунта в осенний период в Московской области // Перспективы использования инновационных форм удобрений, средств защиты и регуляторов роста растений в агротехнологиях сельскохозяйственных культур: Материалы докладов участников 10-й научно-практической конференции "Анапа-2018" / Под ред. акад. РАН В.Г.Сычева. - М.: ООО "Плодородие", 2018. С. 98-101.

31. Зеленков В.Н., Петриченко В.Н., Потапов В.В. Эффективность применения комплексного препарата нового поколения крезацина с гидротермальным нанокремнеземом при внекорневой обработке картофеля в условиях Ростовской области // Материалы Всероссийской научно-практической конференции "Проблемы и перспективы развития сельского хозяйства юга России". - Майкоп: ООО "Качество", 2018. С. 90-94.

32. Зеленков В.Н., Петриченко В.Н., Иванова М.И., Латушкин В.В., Новиков В.Б., Потапов В.В., Елисеева Л.Г., Леонова И.Б. Проверка комплексного состава препарата гидротермального нанокремнезема с крезацином для выращивания салата листового в системе фитотрона ИСР-0.1 // Сборник научных трудов "Жизненный цикл и экология растений: регуляция и управление средой обитания в агробиотехносистемах". Вып. 1. - М.: ТЕХНОСФЕРА, 2018. C. 56-69. 